ASLI QoL 2021

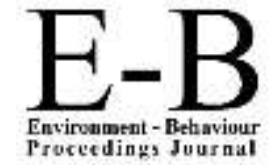

Proceeding, Juarnal

\section{AQoL2021Langkawilsland}

https://www.amerabra.org; https://fspu.uitm.edu.my/cebs; https://www.emasemasresources.com/

$5^{\text {th }}$ ABRA International Conference on Quality of Life

Holiday Villa Langkawi, Langkawi Island, Malaysia, 15-16 Dec 2021

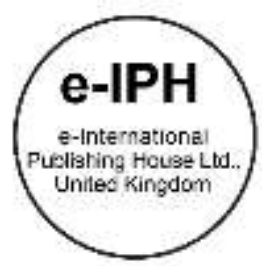

\title{
Examining the Concept of Liveability in Urban Neighbourhoods in Iskandar Malaysia
}

\author{
Wan Azlina Wan Ismail ${ }^{1}$, Nicola Dempsey ${ }^{2}$ \\ 1 Department of Landscape Architecture, Faculty of Architecture and Ekistics, University Malaysia Kelantan, Malaysia \\ ${ }^{2}$ Department of Landscape Architecture, Faculty of Social Science, University of Sheffield, United Kingdom \\ azlina@umk.edu.my,n.dempsey@sheffield.ac.uk \\ Tel: +60129875494
}

\begin{abstract}
Liveability is a critical concept in urban planning and geography. It is well-used in planning policy with different geographical contexts; however, there are limitations in understanding this concept in the Malaysian context. This research examines the relationship of liveability between people and places in their daily lives in urban neighbourhoods through residents' perceptions. Quantitative data collected in 5 urban neighbourhoods in Iskandar Malaysia suggests that liveability must correspond to residents' requirements for good quality facilities and services, good neighbourhood conditions and positive community engagement.
\end{abstract}

Keywords: Liveability Dimensions; Policy Interpretation; Urban Neighbourhood; Iskandar Malaysia

eISSN: 2398-4287@ 2021. The Authors. Published for AMER ABRA cE-Bs by e-International Publishing House, Ltd., UK. This is an open access article under the CC BYNCND license (http://creativecommons.org/licenses/by-nc-nd/4.0/). Peer-review under responsibility of AMER (Association of Malaysian Environment-Behaviour Researchers), ABRA (Association of Behavioural Researchers on Asians/Africans/Arabians) and CE-Bs (Centre for Environment-Behaviour Studies), Faculty of Architecture, Planning \& Surveying, Universiti Teknologi MARA, Malaysia.

DOI: https://doi.org/10.21834/ebpj.v6i18.3084

\subsection{Introduction}

The concept of liveability embodies the idea that the characteristics of places can provide a good quality of life. Researchers worldwide have discussed liveability in urban settings as early as the 1980s (Myers, 1987; Omuta, 1988; Veenhoven, 1996). In 1998, the Western Australian Government introduced their Liveable Neighbourhoods Design Code, providing design principles to enhance the health and wellbeing of residents in new suburban developments (Bull, 2015). The policy was created to guide the growth of more compact and sustainable suburban neighbourhoods to decrease car dependency, encourage walking, cycling, use of public transport, and foster a sense of community. The concept of liveability is mainly linked to cities' economic growth and performance, socio-economic development patterns at the neighbourhood scale, and identified the optimum governance arrangements for local regeneration policies. In Malaysia, the concept of "liveable communities" was introduced in a policy document after the Federal Malaysian government developed the SouthJohor Economic Region as a significant corridor for economic development. The vision, known as Iskandar Malaysia (IM), has been facilitated through a Comprehensive Development Plan (CDP), the underpinning strategy to boost the physical and economic development of the Johor Bahru metropolitan area since 2006 (Rizzo \& Glasson, 2012).

From a policy perspective, liveability is a broad term (Lloyd, Fullagar, \& Reid, 2016), with structural explanations referring to economic and material forces (Béland, 2017). This paper explores how the institutional explanations use common meanings to examine how they are interpreted in practice in 5 urban neighbourhoods in Iskandar Malaysia. The paper suggested how governments need to examine how liveability is supported in practice to compare with policy commitments. Authorities and policymakers should prioritise the evaluation and

eISSN: 2398-4287@ 2021. The Authors. Published for AMER ABRA cE-Bs by e-International Publishing House, Ltd., UK. This is an open access article under the CC BYNCND license (http://creativecommons.org/licenses/by-nc-nd/4.0/). Peer-review under responsibility of AMER (Association of Malaysian Environment-Behaviour Researchers), ABRA (Association of Behavioural Researchers on Asians/Africans/Arabians) and CE-Bs (Centre for Environment-Behaviour Studies), Faculty of Architecture, Planning \& Surveying, Universiti Teknologi MARA, Malaysia.

DOI: https://doi.org/10.21834/ebpj.v6i18.3084 
maintenance of liveability policies as part of the decision-making and development that shape the urban social, economic and physical environments (Foster, Hooper, Knuiman, Bull, \& Giles-Corti, 2015; Hyra, 2012; Ruth \& Franklin, 2014). By means to translate policies effectively into the lived experience of liveability in urban neighbourhoods. Therefore, this research aimed to measure the limitation of liveability policy implemented in the Iskandar Malaysia urban neighbourhoods through residents' perception of their everyday life experiences.

\subsection{Theoretical Background}

Many researchers describe liveability as an emerging theme in urban geography and urban planning (Gieling \& Haartsen, 2017; Gough, 2015; Lowe et al., 2015; Ruth \& Franklin, 2014). It is also a well-established concept in the planning policy implemented by governments and international organisations (Mcarthur \& Robin, 2019). The relationship between people and place in daily life is crucial for the quality of individuals' lives and social cohesion at large (Gustafson, 2001). Previous studies have examined individuals' experiences in specific places and communities, including home (family, relations, and friends), workplace (colleagues), and place of worship (fellow worshippers), neighbourhood (neighbours), city, country, or continent. Positive experiences of places make a positive contribution to one's sense of identity which also enrich life with values, goals, and significance (Carmona, 2019; Giuliani, 2003; Ujang, 2012; Ujang \& Zakariya, 2015) whenever a 'good place' to live, raise a family, and make home was chosen. Moreover, the choices regarding a place to live were made according to employment/ economic factors.

Recent research has attempted to explore the relationships of liveability between places and communities more fully. This includes an interest in investigating liveability in rapidly urbanising settlements within the context of increased globalisation. The liveability of urban neighbourhoods encompasses the correlative relationship between social (communities) and spatial qualities of particular (physical) places while meeting people's needs and adapting to their activities (Jalaladdini \& Oktay, 2012). (Jenks \& Dempsey, 2007) found that thriving neighbourhoods can be examined through their spatial attributes. These attributes refer to the complex socio-psychological-spatial manifestations of place, underpinned by a sense of place attachment and identity.

As various approaches are used to measure the liveability of urban life, (Veenhoven, 1996) acknowledged the liveability of the nation in matters corresponding to social equity and equality. The concept of liveability is defined as the degree to which its provisions and requirements fit with the needs and capacities of its citizens. Engagement with the community and environment comprises bio-physiological needs such as food, safety, and contacts. Therefore, a nation is not liveable if, for instance, these needs are not fulfilled. For this paper, liveability measures the quality of life that a city can afford its inhabitants, making it essential to understand different stakeholder groups' perspectives utilising this concept: policymakers, academics, private providers, and residents.

\subsection{Various Contexts of Liveability}

In operational policies, liveability is used to design and implement structural plans at the regional, district, and local levels. It is frequently applied to neighbourhood areas in urban settlements (Rowe Group, 2015). Despite the recurrent use of 'liveability' in policy, academia and practices, it is an ambiguous term used differently by various groups within different social, physical, environmental, geographical, and economic contexts (Kashef, 2016). These contexts are relevant at various scales and levels, such as individual, household, street, and neighbourhood, relevant to this paper.

The Western Australia Government's Liveable Neighbourhoods Design Code (LN) (1998) arguably play a vital role in helping to build or shape neighbourhoods where residents can live safely, conveniently, and be physically active (Hooper, Giles-Corti, \& Knuiman, 2014; Lowe et al., 2015). While in the UK, the concept of liveability is used to guide economic growth in English cities, primarily about creating places where people would choose to live and work in the present and future (Neam, 2012). In this context, liveability was concerned with the quality of space and the built environment and emphasised peoples' perceptions of comfort and safety of a place (Dempsey, Bramley, Power, \& Brown, 2011; Neam, 2012).

Meanwhile, in Malaysia, the concept of "liveable communities" was introduced in the early 2000s in the Iskandar Malaysia Region's Comprehensive Development Plan (CDP). The policy and strategy of 'liveable communities' here proposed to improve the environment of both new and old neighbourhoods to boost the physical and economic development of the Johor Bahru metropolitan area (CDP, 2006). The strategies aimed to create liveable communities through quality housing, adequate facilities, quality services, and a healthy, safe, and lively environment.

\subsection{Measuring Liveability in Iskandar Malaysia}

The concept of liveability for IM was verified through critical policy evaluation of the CDP and operationalised by exploring the actions and presumptions through various projects and programmes set out by the local authorities of IM or its strategies mentioned in the previous section. In gaining further understanding of liveability in the context of IM's urban neighbourhoods, this research categorised the measurement into three primary dimensions, namely accessibility, equitability, safety/wellbeing, as presented in Table 1.

The indicators in Table 1 are used in a local scale investigation conducted in IM to explore the relationship between CDP policies and practice as experienced by residents in their everyday lives. A range of indicators is adopted from international measures established by many local authorities to measure liveability at the neighbourhood level. Essentially, measuring liveability involves examining people's 
psychological experience variations according to demographic characteristics and geographical scale (Scannell \& Gifford, 2017). Therefore, (Farquhar, 2012) suggested that a case study would contribute to this subject's particular understanding or insight.

Table 1. The operationalized measures of liveability as specified by three primary dimensions

\begin{tabular}{|c|c|c|}
\hline Dimension & Sub-dimension & Operationalize measure (indicator) \\
\hline Accessibility & 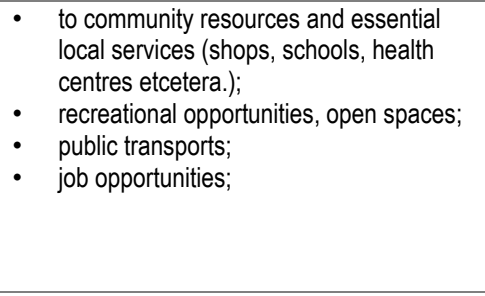 & $\begin{array}{l}\text { A question to determine respondents' accessibility towards daily } \\
\text { places and activities. } \\
\text { - Distance to workplace/school daily activities...? } \\
\text { - Frequency visiting usual places } \\
\text { - Are you visiting the recreational area? } \\
\text { - Where is it located? } \\
\text { - How do you travel to work/school/shop, etc.? } \\
\text { - Where do you work? }\end{array}$ \\
\hline Equitability & $\begin{array}{l}\text { - Sense of place/attachment to } \\
\text { neighbourhood/social interaction/ } \\
\text { satisfaction within the home and } \\
\text { neighbourhood area/participation in } \\
\text { collective group/civic activities. } \\
\text { - Infrastructures; } \\
\text { - } \quad \text { Transportations; } \\
\text { - } \text { Affordable housing; } \\
\text { - Historical/heritage preservation etc. }\end{array}$ & $\begin{array}{l}\text { Measures of equitability } \\
\text { e.g. } \\
\text { - } \quad \text { Occupation } \\
\text { - } \quad \text { House ownership } \\
\text { - Number of vehicles owned } \\
\text { - } \quad \text { Tymbe of house unit }\end{array}$ \\
\hline $\begin{array}{l}\text { Safety/security and } \\
\text { well being }\end{array}$ & $\begin{array}{l}\text { - Improve infrastructure/ transports quality; } \\
\text { Neighbourhood safety/security (from the } \\
\text { risk of crime, antisocial behaviour, social } \\
\text { issues, etc.; } \\
\text { - Quality of local environment, public } \\
\text { fitness and health. }\end{array}$ & $\begin{array}{l}\text { Measures of safety/security and wellbeing } \\
\text { e.g. } \\
\text { - } \quad \text { Feeling safe at home in the day time and after dark } \\
\text { - The crime occurred in your neighbourhood } \\
\text { - } \quad \text { Contact with neighbours } \\
\text { Social values }\end{array}$ \\
\hline
\end{tabular}

(Source:) Author, 2019

\subsection{Data and Methods}

\subsubsection{Data}

This study consists of a quantitative research approach where IM residents' perspectives are compared to the definition of liveable policies set up in the CDP. Some of the questionnaires were adopted from previous relevant research similar in study approach and objectives (Bramley, Dempdey, Power, Brown, \& Watkins, 2009; Dempsey et al., 2011; Leby \& Hashim, 2010; Norouzian-Maleki, Bell, Hosseini, \& Faizi, 2015; Saitluanga, 2014; Sedaghatnia, Lamit, Ghahramanpouri, \& Mohamad, 2013).

According to the CDP, five urban neighbourhoods were identified and provided diversity in terms of neighbourhood characteristics and demographics. Three hundred six (306) valid responses using probability sampling between September to December 2016 from adult residents aged $18+$ residing in 5 neighbourhoods. The total response rate varies for gender, with $35 \%$ male and $65 \%$ female. The study participants were approached in each neighbourhood. They were conducted in places where residents were expected to perform their daily activities, such as local schools, places of work, shopping, or leisure time. The indicators to measure accessibility were separated into two categories: lived experience and residents' perceptions via survey questions utilising the Likert scale and open-ended opinion questions.

\subsubsection{Statistical Analysis}

Exploratory Factor Analysis (EFA) was used to explore the underlying structure of liveability indicators and a more detailed review of the dimension of liveability. Initially, the correlation matrix of the association was evaluated using Principal Component Analysis (PCA) to identify and compute composite scores for the factors which underpin the liveability dimensions. EFA defined the liveability indicators assigned to capture relevant variables (Tabachnick \& Fidell, 2013) there were six factors. This was checked using PCA for all scales using the Oblimin rotation method to create more reliable factorial solutions, considering that Kaiser Normalisation excluded any indicators used to measure liveability in the questionnaire survey, which was not represented.

The indicators considered to constitute the underlying indicators of the primary dimension of liveability in this study were identified in the initial eigenvalues or the factors' variances (Table 2). Using a correlation matrix with standardised variables, indicating that each variable had a variance of 1 (after (Pallant, 2013), there were six factors. Next, it was checked using PCA for all scales using the Oblimin rotation method to create more reliable factorial solutions, considering that Kaiser Normalisation excluded any indicators used to measure liveability in the questionnaire survey which was not represented. The underlying components extracted from the overall data set were then clustered according to factor loadings produced in the pattern matrix table. All the 31 items from the questionnaire tested in EFA were categorised based on the value loadings, as shown in Table 2. 
Table 2. Summary of the results of residents' perception of liveability dimension based on Exploratory Factor Analysis (EFA)

\begin{tabular}{|c|c|c|c|c|c|c|}
\hline \multirow[b]{2}{*}{ Indicators items } & \multicolumn{6}{|c|}{ Factor Loadings } \\
\hline & $\begin{array}{l}\text { Local problems } \\
\text { and } \\
\text { maintenance }\end{array}$ & $\begin{array}{l}\text { Perception of } \\
\text { Neighbourhood }\end{array}$ & Crime & $\begin{array}{l}\text { Facilities and } \\
\text { local services }\end{array}$ & Safety & $\begin{array}{l}\text { Community } \\
\text { and social } \\
\text { value }\end{array}$ \\
\hline Poor street lighting & .838 & & & & & \\
\hline Poor road condition & .806 & & & & & \\
\hline Poor drainage system & .795 & & & & & \\
\hline Poor air quality & .746 & & & & & \\
\hline Litter and graffiti & .663 & & & & & \\
\hline Proximity to traffic & .624 & & & & & \\
\hline Lack of car park & .553 & & & & & \\
\hline $\begin{array}{l}\text { Disturbance by } \\
\text { youngster/children }\end{array}$ & .433 & & & & & \\
\hline Crime in the area & .414 & & .385 & & & \\
\hline Noise from neighbours & .413 & & & & & \\
\hline $\begin{array}{l}\text { General surrounding } \\
\text { appearance }\end{array}$ & & .778 & & & & \\
\hline $\begin{array}{l}\text { Condition of homes and } \\
\text { surrounding }\end{array}$ & & .768 & & & & \\
\hline $\begin{array}{l}\text { Your neighbourhood as } \\
\text { a place to live }\end{array}$ & & .745 & & & & \\
\hline $\begin{array}{l}\text { Provision of recreational } \\
\text { facilities }\end{array}$ & & .723 & & & & \\
\hline $\begin{array}{l}\text { I feel safe living in this } \\
\text { neighbourhood }\end{array}$ & & .472 & & & & \\
\hline Provision of shops & & .465 & & .355 & & \\
\hline Theft & & & .909 & & & \\
\hline Burglary & & & .908 & & & \\
\hline Violence & & & .879 & & & \\
\hline Vandalism & & & .821 & & & \\
\hline Drug/alcohol use & & & .774 & & & \\
\hline $\begin{array}{l}\text { The local services and } \\
\text { facilities are convenient } \\
\text { in this neighbourhood }\end{array}$ & & & & .875 & & \\
\hline $\begin{array}{l}\text { The public transport } \\
\text { services are reliable in } \\
\text { this neighbourhood }\end{array}$ & & & & .866 & & \\
\hline $\begin{array}{l}\text { The local services and } \\
\text { facilities are reachable } \\
\text { in this neighbourhood }\end{array}$ & & & & .864 & & \\
\hline $\begin{array}{l}\text { Alone at home after } \\
\text { dark }\end{array}$ & & & & & .755 & \\
\hline $\begin{array}{l}\text { Alone at home during } \\
\text { the day }\end{array}$ & & & & & .712 & \\
\hline $\begin{array}{l}\text { Walking alone in your } \\
\text { area during the day }\end{array}$ & & & & & .700 & \\
\hline $\begin{array}{l}\text { Walking alone in your } \\
\text { area after dark }\end{array}$ & & & & & .669 & \\
\hline $\begin{array}{l}\text { Sense of community } \\
\text { spirit in your } \\
\text { neighbourhood }\end{array}$ & & & & & & .896 \\
\hline $\begin{array}{l}\text { Helpfulness in your } \\
\text { neighbourhood }\end{array}$ & & & & & & .887 \\
\hline $\begin{array}{l}\text { Friendliness in your } \\
\text { neighbourhood }\end{array}$ & & & & & & .872 \\
\hline $\begin{array}{l}\text { Extraction Method: Princip } \\
\text { Rotation Method: Oblimin } \\
\text { a. Rotation converged in } 9\end{array}$ & $\begin{array}{l}\text { mponent Analysis } \\
\text { Kaiser Normalization } \\
\text { tions }\end{array}$ & & & & & \\
\hline
\end{tabular}


Based on the data, the liveability indicators of IM could be elaborated according to the respondents' interpretation of this concept, namely (i) local problems and maintenance (street lights, road condition, drainage system, air quality, etcetera), (ii) perception of the neighbourhood (condition of homes and general surrounding), (iii) crimes (theft, burglary, violence, and vandalism), (iv) facilities and local services (convenience and access to local services and facilities, the reliability of public transport), (v) safety (safety in different situations such as being alone at home after the dark and during the day, walking alone in your area after the dark and during the day), and (vi) community and social value (sense of community, helpfulness, friendliness in the communities).

EFA identified that residents responded to the questionnaire survey and suggested a new category of indicators based on their interpretation. To understand the relationship between different perceptions of liveability, the effects of demographic variables on the neighbourhood level were identified using Multilevel ANOVA. This analysis was used to compare the demographic characteristics of IM residents and their effects on various six outcome dimensions from the EFA presented in Table 2. The correlations between sociodemographic variables and the six new factors were tested using statistical tests such as one-way, two-way, and higher factorial designs (Pallant, 2013). The neighbourhood level was used as a random factor to fulfil its purposes. It was found that socio-demographic variables could affect residents' perceptions of liveability. The results shown in Table 3 indicates that there might be a significant relationship between the factors and one or more demographic characteristics. At the same time, some of them were not related to any demographic element.

Table 3. The relationship of liveability factors with demographics characteristics

\begin{tabular}{|c|c|c|c|c|c|c|}
\hline \multirow{2}{*}{$\begin{array}{l}\text { Demographic } \\
\text { characters }\end{array}$} & \multicolumn{6}{|c|}{ Liveability indicators constructed from EFA } \\
\hline & $\begin{array}{l}\text { Local problems } \\
\text { and } \\
\text { maintenance }\end{array}$ & $\begin{array}{l}\text { Perception of } \\
\text { Neighbourhood }\end{array}$ & Crime & $\begin{array}{l}\text { Facilities and } \\
\text { local services }\end{array}$ & Safety & $\begin{array}{c}\text { Community } \\
\text { and social } \\
\text { value }\end{array}$ \\
\hline Gender & $x$ & $p=0.003$ & $x$ & $x$ & $x$ & $x$ \\
\hline Ethnicity & $x$ & $x$ & $x$ & $x$ & $x$ & $x$ \\
\hline Age & $p=0.019$ & $p=0.027$ & $x$ & $x$ & $x$ & $x$ \\
\hline $\begin{array}{r}\text { Educational } \\
\text { level }\end{array}$ & $x$ & $x$ & $x$ & $p=0.002$ & $x$ & $p=0.041$ \\
\hline $\begin{array}{r}\text { Current job } \\
\text { status }\end{array}$ & $x$ & $x$ & $p=0.002$ & $x$ & $x$ & $x$ \\
\hline Job category & $x$ & $x$ & $x$ & $x$ & $x$ & $x$ \\
\hline $\begin{array}{r}\text { Monthly } \\
\text { household } \\
\text { income }\end{array}$ & $x$ & $x$ & $x$ & $p=0.002$ & $x$ & $x$ \\
\hline $\begin{array}{r}\text { Household's } \\
\text { size }\end{array}$ & $x$ & $x$ & $x$ & $x$ & $x$ & $x$ \\
\hline House unit & $x$ & $x$ & $x$ & & $x$ & $x$ \\
\hline
\end{tabular}

(Source:) Author, 2019

\subsection{Findings and Discussion}

The findings suggest that measuring the liveability of urban neighbourhood environments in Iskandar Malaysia is imperative to understand the meaning and interpretation of this concept in a specific context. This research attempted to measure liveability based on the constructed dimensions, namely accessibility, equitability, and safety and wellbeing. As a result, it was found that the dimensions were interpreted in different ways after they were subjected to an Exploratory Factor Analysis (EFA) using the PCA method. It demonstrated how residents interpreted liveability into six new components (dimensions), which were (i) local problems and maintenance, (ii) perception of neighbourhood, (iii) crime, (iv) facilities and local services, (v) safety, (vi) community and social value. The local problems and maintenance dimension highlighted several local environmental issues, such as street lighting, road condition, drainage system, and air quality. The neighbourhood environment indicator referred to the condition of homes and general surroundings. Moreover, the facilities and local services indicator underlined the level of convenience, accessibility to local services and facilities among the residents, and the reliability of public transports. It was followed by community and social values, highlighting its sense of community, helpfulness, and friendliness.

The policy and strategy of creating a liveable community in Iskandar Malaysia's urban neighbourhood contrasted with the research expectations. The strategies and action plans were described broadly using general terms. These general terms did not correspond to residents' interpretations of liveability as outlined above. Overall, the findings identify corresponding interpretations of liveability made by previous works of literature so far.

This discussion aimed to identify the possible associations and implications to determine the nature of the relationship between the findings. Moreover, some statistical analyses, such as correlation and multilevel ANOVA, were conducted to identify the association between the factors that measured each neighbourhood's liveability. The conceptual interpretation of liveability is identified through the primary dimensions of this research. The results nevertheless found that accessibility emphasised the accessibility to the green facilities and modes of travelling within the neighbourhood. The equitability in the neighbourhood emphasised equitable access to schools, educational facilities, health care services, places of worship, and public transport. The dimension of safety encompassed the residents' 
perceptions of it in several specific circumstances. It was indicated through safe neighbourhoods that, in terms of lived experience, residents expressed dissatisfaction with the local government's performance in handling crime issues. However, they were convinced that the local authority had made significant efforts to address them. Finally, wellbeing is a dimension of liveability which is constantly related to community engagement and social interaction. This dimension emphasises social networks, social cohesion, and sustainable neighbourhood design. It was found that the factors which influenced social wellbeing were tenancy status, household size, the interaction between communities, a good lifestyle, and specific physical environments.

\subsection{Conclusion and Recommendations}

Based on understandings gained from previous works of literature, this research shows that for liveability to be effectively measured in a particular context, it must be interpreted beyond the physical setting to include residents' social needs and interactions.

Further research should not assume that the developers, urban designers, planners, and architects will achieve the goal of liveability in the planning policy when creating, designing, or renewing the built environment of the urban neighbourhood. It should be noted that liveability is encompassed within the definition of sustainability and quality of life of a specific context and setting. Therefore, the 'liveable communities' as presented in the CDP and some other terms used in the Malaysian planning strategies to address this goal should be interpreted carefully according to the need and appropriateness of the socio-spatial context and setting.

Liveability in urban neighbourhoods can be achieved by emphasising the quality of the built environment and the social dimension significantly in the local communities (Zhang \& Lawson, 2009). As these research findings show, the social dimension of liveability should be addressed in the policies and services developed and provided by public agencies to improve the quality of life for all citizens. It is suggested that policies relating to safety, education, women, families and communities, youth provision, local services, housing provision and regeneration programmes in Malaysia should be addressed to tackle this issue precisely.

\section{Acknowledgements}

The authors sincerely acknowledge the Research Management \& Innovation Centre (RMIC) of University Malaysia Kelantan (UMK), and the Ministry of Education (MOE) of the Government of Malaysia for the funding of this research through research grant no. R/FRGS/A1200/00136A/002/2020/00885.

\section{Paper Contribution to Related Field of Study}

This study may be necessary for policy, practice, theory, and subsequent research in the urban neighbourhood and academic practices. The findings are broad and could be scrutinised at different levels of revising the urban policy for the future development of neighbourhood design in Iskandar Malaysia and elsewhere in the urbanising parts of the country.

\section{References}

Béland, D. (2017). Identity, Politics, and Public Policy. Critical Policy Studies, 11(1), 1-18. https://doi.org/10.1080/19460171.2016.1159140

Bramley, G., Dempdey, N., Power, S., Brown, C., \& Watkins, D. (2009). Social sustainability and urban form: Evidence from five British cities. Environment and Planning A, 41(9), 2125-2142. https://doi.org/10.1068/a4184

Bull, F. et al. (2015). Living Liveable. The Impact of the Liveable Neighbourhoods Policy on the health and wellbeing of Perth residents. Western Australia.

Carmona, M. (2019). Place value : place quality and its impact on health , social , economic and environmental outcomes. Journal of Urban Design, 24(1), 1-48. https://doi.org/10.1080/13574809.2018.1472523

CDP. (2006). Chapter 4: Economic Development Strategies. Comprehensive Development Plan 2006-2025 for South Johor Economic Region.

Conteh, F. M., \& Oktay, D. (2016). Measuring liveability by exploring urban qualities of Kissy Street, Freetown, Sierra Leone. Open House International, 41(2), 23-30.

Dempsey, N., Bramley, G., Power, S., \& Brown, C. (2011). The Social Dimension of Sustainable Development: Defi ning Urban Social Sustainability. Sustainable Development, 19(May 2009), 289-300. https://doi.org/10.1002/sd.417

Farquhar, J. D. (2012). What is Case Study. Case Study Research for Business, 3-14. https://doi.org/10.7748/nr2000.01.7.2.5.c6109

Foster, S., Hooper, P., Knuiman, M., Bull, F., \& Giles-Corti, B. (2015). Are liveable neighbourhoods safer neighbourhoods? Testing the rhetoric on new urbanism and safety from crime in Perth, Western Australia. Social Science and Medicine, 4-11. https://doi.org/10.1016/j.socscimed.2015.04.013

Gieling, J., \& Haartsen, T. (2017). Liveable Villages: The Relationship between Volunteering and Liveability in the Perceptions of Rural Residents. Sociologia Ruralis, 57(November), 576-597. https://doi.org/10.1111/soru.12151

Girardi, P., \& Temporelli, A. (2017). Smartainability : a methodology for assessing the sustainability of the smart city. Energy Procedia, 111(September 2016), 810-816 https://doi.org/10.1016/j.egypro.2017.03.243

Giuliani, M. V. (2003). Theory of Attachment and Place Attachment. Psychological Theories for Environmental Issues, (June). 
Gough, M. Z. (2015). Reconciling Livability and Sustainability: Conceptual and Practical Implications for Planning. Journal of Planning Education and Research, 35(2), 145-160. https://doi.org/10.1177/0739456X15570320

Gustafson, P. (2001). Meanings of Place: Everyday Experience and Theoretical Conceptualizations. Journal of Environmental Psychology, 21, 5-16. https://doi.org/10.1006/jevp.2000.0185

Hooper, P., Giles-Corti, B., \& Knuiman, M. (2014). Evaluating the implementation and active living impacts of a state government planning policy designed to create walkable neighborhoods in Perth, Western Australia. American Journal of Health Promotion, 28(SUPPL 3), 5-19. https://doi.org/10.4278/ajhp.130503-QUAN-226

Hyra, D. S. (2012). Conceptualizing the New Urban Renewal: Comparing the Past to the Present. Urban Affairs Review, 48(4), 498-527. https://doi.org/10.1177/1078087411434905

Iyanda, S. A., \& Mohit, M. A. (2016). Measuring the Dimensions and Attributes of Liveability of Low-Income Housing Communities in Nigeria. Journal of The Malaysian Institute of Planners Institute, (Special Issue IV), 383-394.

Jalaladdini, S., \& Oktay, D. (2012). Urban Public Spaces and Vitality: A Socio-Spatial Analysis in the Streets of Cypriot Towns. Procedia - Social and Behavioral Sciences, 35(December 2011), 664-674. https://doi.org/10.1016/j.sbspro.2012.02.135

Jenks, M., \& Dempsey, N. (2007). Defining the neighbourhood: challenges for empirical research. Town Planning Review, 78(2), 153-178. https://doi.org/10.2307/40112711

Kashef, M. (2016). Urban livability across disciplinary and professional boundaries. Frontiers of Architectural Research, 5(2), 239-253. https://doi.org/10.1016/j.foar.2016.03.003

Leach, J. M., Braithwaite, P. A., Lee, S. E., Bouch, C. J., Hunt, D. V. L., \& Rogers, C. D. F. (2016). Measuring urban sustainability and liveability performance: the City Analysis Methodology. International Journal of Complexity in Applied Science and Technology, 1(1), 86-106. https://doi.org/10.1504/IJCAST.2016.081296

Leby, J. L., \& Hashim, A. H. (2010). Liveability Dimensions and Attributes: Their Relative Importance in the Eyes of Neighbourhood Residents. Journal of Construction in Developing Countries, 15(1), 67-91.

Lloyd, K., Fullagar, S., \& Reid, S. (2016). Where is the 'Social' in Constructions of 'Liveability'? Exploring Community, Social Interaction and Social Cohesion in Changing Urban Environments. Urban Policy and Research, 34(4), 343-355. https://doi.org/10.1080/08111146.2015.1118374

Lowe, M., Whitzman, C., Badland, H., Davern, M., Aye, L., Hes, D., ... Giles-Corti, B. (2015). Planning Healthy, Liveable and Sustainable Cities: How Can Indicators Inform Policy? Urban Policy and Research, 1146(June), 1-14. https://doi.org/10.1080/08111146.2014.1002606

Mcarthur, J., \& Robin, E. (2019). Victims of their own (definition of) success : Urban discourse and expert knowledge production in the Liveable City. Urban Studies, 1(18), 36-38. https://doi.org/10.1177/0042098018804759

Myers, D. (1987). Community-Relevant Measurement of Quality of Life : A Focus on Local Trends. Urban Affairs Quarterly. https://doi.org/0803973233

Neam, B. (2012). Measuring the Social Sustainability of Urban Communities : the Role of Local Authorities. Transylvanian Review of Administrative Sciences, (37E), 112127.

Norouzian-Maleki, S., Bell, S., Hosseini, S. B., \& Faizi, M. (2015). Developing and testing a framework for the assessment of neighbourhood liveability in two contrasting countries: Iran and Estonia. Ecological Indicators, 48, 263-271. https://doi.org/10.1016/j.ecolind.2014.07.033

Omuta, G. E. . (1988). The quality of urban life and the perception of livability: A case study of neighbourhoods in Benin City, Nigeria. Social Indicators Research, 20(4), 417-440. https://doi.org/10.1007/BF00302336

Pallant, J. (2013). SPSS Survival Manual - A step by step guide to data analysis using IBM SPSS. 5th Edition (5th ed.). London.

Paul, A., \& Sen, J. (2018). Livability assessment within a metropolis based on the impact of integrated urban geographic factors ( IUGFs ) on clustering urban centers of Kolkata. Cities, 74(June 2017), 142-150. https://doi.org/10.1016/j.cities.2017.11.015

Rizzo, A., \& Glasson, J. (2012). Iskandar Malaysia. Cities, 29(6), 417-427. https://doi.org/10.1016/j.cities.2011.03.003

Rowe Group. (2015). REVIEW OF DRAFT LIVEABLE NEIGHBOURHOODS. Australia.

Ruth, M., \& Franklin, R. S. (2014). Livability for all? Conceptual limits and practical implications. Applied Geography, 49, 18-23. https://doi.org/10.1016/j.apgeog.2013.09.018

Saitluanga, B. L. (2014). Spatial Pattern of Urban Livability in Himalayan Region: A Case of Aizawl City, India. Social Indicators Research, 117(2), 541-559. https://doi.org/10.1007/s11205-013-0362-3

Scannell, L., \& Gifford, R. (2017). The experienced psychological benefits of place attachment. Journal of Environmental Psychology, 51, 256-269. https://doi.org/10.1016/j.jenvp.2017.04.001

Sedaghatnia, S., Lamit, H., Ghahramanpouri, A., \& Mohamad, S. (2013). An Evaluation of Residents' Quality of Life through Neighborhood Satisfaction in Malaysia. Environmental Management and Sustainable Development, 2(1), 114-125. https://doi.org/10.5296/emsd.v2i1.3254

Tabachnick, B. G., \& Fidell, L. S. (2013). Using multivariate statistics (6th ed.). Pearson Education. https://doi.org/10.1037/022267

Tilaki, M. J. M., Abdullah, A., Bahauddin, A., \& Marzbali, M. H. (2014). The Necessity of Increasing Livability For George Town World Heritage Site: An Analytical Review. 
Modern Applied Science, 8(1), 123-133. https://doi.org/10.5539/mas.v8n1p123

Turkoglu, H. (2015). Sustainable Development and Quality of Urban Life. Procedia - Social and Behavioral Sciences, 202(December 2014), 10-14. https://doi.org/10.1016/j.sbspro.2015.08.203

Ujang, N. (2012). Place Attachment and Continuity of Urban Place Identity. Procedia - Social and Behavioral Sciences, 49, $156-167$. https://doi.org/10.1016/j.sbspro.2012.07.014

Ujang, N., \& Zakariya, K. (2015). The Notion of Place, Place Meaning and Identity in Urban Regeneration. Procedia - Social and Behavioral Sciences, 170, 709-717. https://doi.org/10.1016/j.sbspro.2015.01.073

Veenhoven, R. (1996). Happy Life-Expectancy : A Comprehensive Measure of Quality-of-Life in Nations. Social Indicators Research, 39(1), 1-58. Retrieved from http://www.jstor.org/page/ info/about/policies/terms.jsp\%0AJSTOR

Zhang, W., \& Lawson, G. (2009). Meeting and greeting: Activities in public outdoor spaces outside high-density urban residential communities. URBAN DESIGN International, 14(4), 207-214. https://doi.org/10.1057/udi.2009.19 